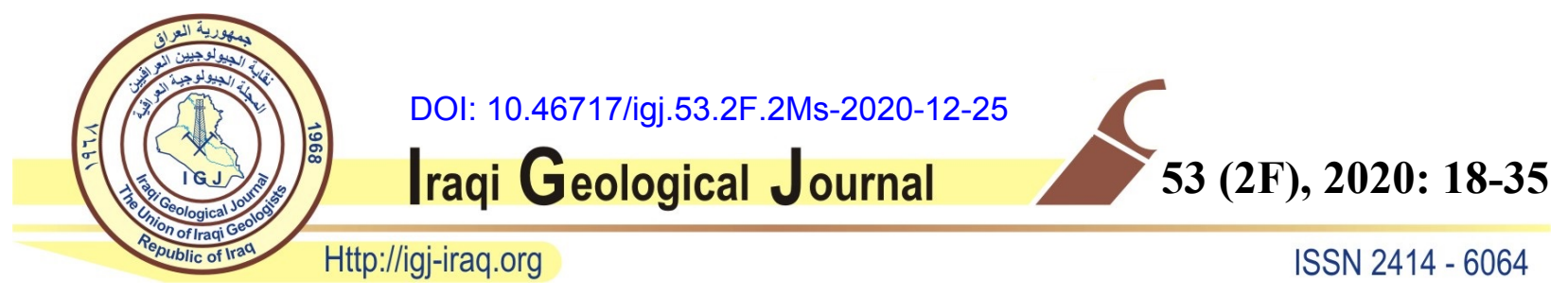

\title{
ENVIRONMENTAL IMPACT ASSESSMENT ON THE EMISSIONS OF QUARRY SITE PROCESSING OF AL-NAWASER CEMENT FACTORY, NW YEMEN
}

\author{
${ }^{1}$ Abdulqader M. Al-Kharraz, ${ }^{2}$ Yassin R. Hassan and ${ }^{3}$ Saad Z. Al-Mashaikie \\ ${ }^{1}$ Department of Marine Environment, Faculty of Marine and Environmental Sciences, Al-Hodiedah University, Yemen \\ ${ }^{2}$ Department of Environmental Engineering, College of Engineering, University of Baghdad, Baghdad, Iraq \\ ${ }^{3}$ Department of Geology, Collage of Science, University of Baghdad, Baghdad, Iraq \\ *E-mails: 3. magnesite2006@gmail.com \\ Received: 9 July 2020; accepted: 23 November 2020
}

\begin{abstract}
Al-Nawaser cement plant is processed to construct in Al-Mahweet, $N W$ Yemen. The quarry area is composed of limestone of Amran Group as a main raw source for cement production, which is exposed in the high mountains beside the plant site. The chemical analysis of limestones shows $50.31 \% \mathrm{CaO}$ content, with $0.71 \% \mathrm{MgO}$. No previous studies were published to discuss the environmental impact assessment in Al-Mahweet, in which Al-Nawaser cement plant is the first to construct in the area. This paper discusses the environmental impacts in the quarry and surrounding area assessing various pollution creates from emitted gases and dust, based on the guidelines of WHO and YEPA specifications. The paper discusses a mitigation plan for dust, gases emissions and noises during the quarrying and trucking processes, to prevent and/or minimize the pollution impacts of $\mathrm{CO}, \mathrm{CO}_{2}, \mathrm{SO}$ and $\mathrm{NOx}$ gases comes from the detonation of the raw materials, viechels and crushers with dust in the quarry site and surrounding area. This study deals with the expected pollution impacts in the quarry site created from blasting and extraction of the raw materials emitted gases and dust directly affect the villages, population, agriculture, surface and ground waters and biodiversity. Moreover, machines (shovels, primary crushers) and trucks operation add another impact source of emitted gases and noises.
\end{abstract}

Keywords: Al-Ghareb; EIA; Emitted gases; Dust pollution; Quarry; Mitigation plan

\section{INTRODUCTION}

Al-Nawaser cement factory is considered as one important project in the development of the Yemeni economic plan for the 2021 year. It is supporting the development of Al-Mahweet to provide job chances and other services. The plant site lies in Wade Ayan beside Jabal Al-Garb 
Mountain; the site of the quarry raw materials (Fig. 1). It is elevated $300 \mathrm{~m}$ a.s.l and lying $100 \mathrm{~km}$ north Al-Hodiedah main port. This study discusses the pollution impacts on the environmental factors, which are affected by various emissions during extracting processes in the quarry area. These processes include extraction of the limestone rocks, as an essential raw material for cement production. Quarry processes include pitting machine, the detonation of the limestone rocks by dynamite, shovels, primary crushers and trucks traffics all together emit actual and polluted dust and gases impact the surrounding areas.

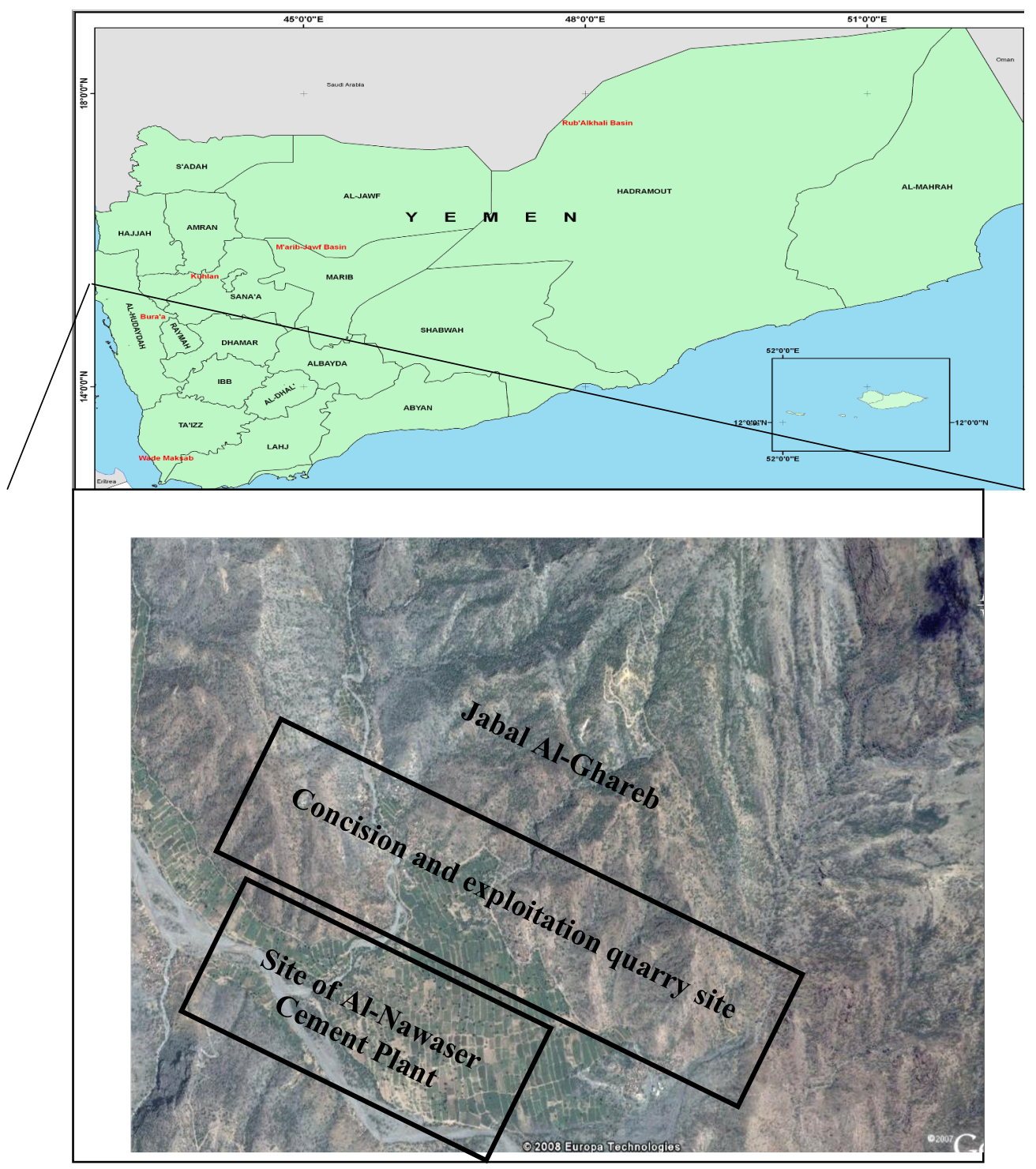

Fig. 1. Location map of Yemen of Al-Ghareb area shows the site of the cement plant in Wade Ayan valley and site of a quarry of the limestone rocks 
Environmental impacts are assessed according to the EPA (2013) guidelines covering environment parameters and the mitigation plan to prevent and reduce the impacts. No previous study was carried out in Yemen except a study of Al-Mashaikie and Al-Karraz (2013) for Al-Marawa'a cement factory in Al-Hodiedah near Bajil City. There are a lot of studies about the environmental impacts of quarry processing edited with all cement factories all over the world.

\section{MATERIALS AND METHODS}

Al-Nawaser cement factory is a site of the field study to survey quarry of the limestone rocks in AL-Ghareb Mountain (Fig.1). Limestone rocks are sampled and evaluated by chemical analysis for cement production and their environmental impacts. The field works include: measurement of weather parameters using Kestrael 4500 device for wind direction, humidity, temperatures and compass, dust measuring device PCE-RCM 05 using for dust particles, humidity and temperature, and noise meter / sound Meter PCE-322ALEQ to measure noise in the field of industrial, health, safety and environmental monitoring. The EIA was followed the guidelines of EPA (EPA, 2013; 2014). Exploitation area of $2 \mathrm{~km}^{2}$ is selected in Al-Ghareb Mountain (Fig.1). Eleven limestone samples are analyzed using XRF in Amran Cement factory followed the procedure in Tucker (1988). Moreover, three water samples were analyzed to evaluate the expected pollution during the quarry operations.

\section{RESULTS AND DESCRIPTION}

\section{Description of The Natural Environment}

\section{Physiography}

The study area is characterized by complex topography comprised high elevated mountains (500 m) cutting by narrow valleys, which are opened toward Tehama plain. The quarry site is height $300 \mathrm{~m}$ a.s.l. Ayan Valley is flowing northwards and opened to the agriculture plan (GSMRB License and report, 2013). The concision area of the quarry covers $1.8 \mathrm{X} 1 \mathrm{~km}^{2}$ (Fig.1).

\section{A. Climate and meteorology}

Meteorological data for the study area is measured in the site and from the meteorological station of Al-Hodiedah City. It is a tropical hot climate and mean monthly temperature ranges from $25{ }^{\circ} \mathrm{C}$ in January to $39.5{ }^{\circ} \mathrm{C}$ in July/August. Annual precipitation is about $400 \mathrm{~mm}$ at the mountains, mostly rainout between 4 to 10 months. The yearly evaporation is about $1864 \mathrm{~mm}$. The climate is reported high humidity cf. about 69 to $76 \%$. Average month temperature is $26{ }^{\circ} \mathrm{C}$ to $34{ }^{0} \mathrm{C}$. The minimum temperature is in January as $25{ }^{\circ} \mathrm{C}$ and $39,5{ }^{\circ} \mathrm{C}$ in July/August. The major wind direction 
is S-SW in January and N-NW in July with maximum speed of $12.1 \mathrm{~m} / \mathrm{sec}$ (Table1). The average values of sunshine periods along Tehama Plan is 7 to $10 \mathrm{~h} /$ day.

Table 1. Meteorological data was measured in Al-Ghareb area using specific devises

\begin{tabular}{|c|c|c|c|c|}
\hline & January/winter & July/summer & Average & Elevation \\
\hline Temperature ${ }^{0} \mathrm{C}$ & 25 & 39.5 & 32.25 & \multirow{5}{*}{$320 \mathrm{~m}$ a.s.l. } \\
\hline Relative humidity \% & $65 \%$ & $71 \%$ & $68 \%$ & \\
\hline Wind velocity $(\mathrm{m} / \mathrm{sec})$ & 10 & 12.1 & 4.15 & \\
\hline Wind direction & S-SW & N-NW & & \\
\hline Rainfall (mm/month) & 2.3 & 17.5 & 9.9 & \\
\hline
\end{tabular}

\section{B. Agriculture}

In Jabal Al-Ghareb, various trees are living in the area. In Wade Ayan valley; the area of study, distributed agricultural fields are distributed and down to the open plain. Corn, vegetables, banana and mango are cultivated in the farms (Fig. 2).

C. Natural environments

Al-Ghareb area includes relatively high biodiversity that represents one of mountainous regions. This environment is providing significant habitat of birds and its migration to another region cf. Songbird, Yemeni Apple Bird ...etc. Various natural animals, tress and vegetables are existed in and around the quarry site cf. Arabian Gazelle, Wild Cat, Panther (Alawi and Mezhelovsky, 1999; MoWE/EPA Report 2004).

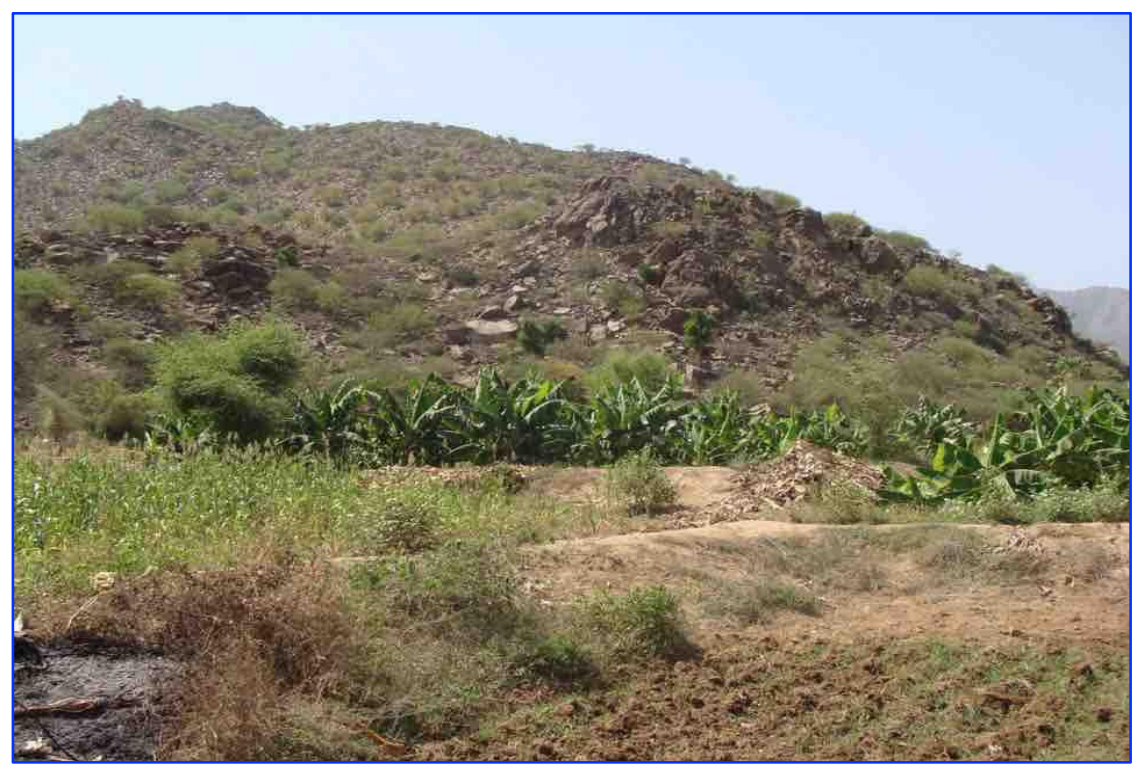

Fig. 2. Field photograph show the study area including the plant diversity, agriculture farms and natural trees in Jabal Al-Ghareb Mountain. The Banana and corn farms near the site 


\section{Human population}

Al-Ghareb area has low human population in two villages lying near the quarry site. Population is growing at about 3.45 percentage in the last few years. This expansion of high population growth reflects important risk to effect the environmental system and consequently the bio-natural fortune.

E. Water resources

The rainfall-fed is the main source of water in the area. In the dry cropping days, the rainfall feds are about $50 \%$ below evapotranspiration. Moreover, the groundwater considered as a main and supplementary source of irrigation. Depletion of the ground waters from 1 to $7 \mathrm{~m}$ per year is resulted from great pumping for agriculture and drinking uses (Alawi and Mezhelovsky, 1999; NWRA, 1999; MoWE/EPA, 2000). The results of chemical and physical analysis of the groundwater in the study area are shown in Table 3 and lies within the limits of the guidelines.

\section{Quarry Site Characterization}

The quarry site of limestone rocks is extended for $2 \mathrm{~km}$ along the western side of Jabal Al-Ghareb Mountain beside Wade Ayan Valley. Agricultural farms are distributed in the area and surface waters is running during the year. Underground water is found in shallow depths of 5 to $10 \mathrm{~m}$. The land surface is elevated little more than $300 \mathrm{~m}$ a.s.1.

Table 2. Analytical results of the groundwater in the study area

\begin{tabular}{|c|c|c|c|c|c|}
\hline Parameters & Result & Specification guide & Parameters & Result & $\begin{array}{c}\text { Specification } \\
\text { guide }\end{array}$ \\
\hline \multicolumn{3}{|c|}{ Physical parameters } & \multicolumn{3}{|c|}{ Chemical parameters } \\
\hline $\mathrm{PH}$ & 7.5 & $6.50-8.0$ & $\mathrm{Cl}(\mathrm{PPM})$ & 50 & Max. 170 \\
\hline T.D.S. (PPM) & 705 & Max. 400 & $\mathrm{NO}_{3}(\mathrm{PPM})$ & 40 & Max. 20 \\
\hline Conductivity $(\mathrm{ms} / \mathrm{cm})$ & 0.810 & Max.0.5 & $\mathrm{Fe}(\mathrm{PPM})$ & Nil & Max. 0.1 \\
\hline Total Hardness as $\mathrm{CaCO}_{3}(\mathrm{PPM})$ & 340 & Max 107 & Mn (PPM & Nil & Max. 0.05 \\
\hline P. Value (Meq/ltr) & Nil & Max. 0.20 & $\mathrm{SiO}_{2}(\mathrm{PPM})$ & 27 & Max. 40 \\
\hline M. Value (Meq/ltr) & 6.0 & Max. 3.0 & $\mathrm{HCO}_{3}(\mathrm{PPM})$ & 366 & Max. 200 \\
\hline Appearance /Color & Normal & Normal & $\mathrm{PO}_{4}(\mathrm{PPM})$ & 0.2 & Max. 0.5 \\
\hline Turbidity & Normal & Normal & Free $\mathrm{Cl}(\mathrm{PPM})$ & Nil & Max. 0.5 \\
\hline \multirow[t]{3}{*}{ Odor (Organoleptic) } & Normal & Normal & $\mathrm{NaCl}(\mathrm{PPM})$ & 80 & Max. 300 \\
\hline & & & $\mathrm{Na}(\mathrm{PPM})$ & 30 & Max. 100 \\
\hline & & & $\mathrm{SO}_{4}(\mathrm{PPM})$ & 72 & Max. 250 \\
\hline Elevation of surface area & $300 \mathrm{~m}$ & Measured by GPS & & & \\
\hline
\end{tabular}

Pit drilling and detonation are used to extract the limestones rocks and later transported by heavy trucks to the storage yard to crush by primary jaw crusher to specify the grain size to smaller sizes (Harrison, 1993). The rock fragments are discharged to hopper (funnel-shape container) to separate sizes using multiple sieves and to minimize the load to the primary crusher (Harrison, 1993, Walter and Werner, 2003). 


\section{A. Quality of limestone raw material}

The main quarry is composed of limestone rocks (Fig. 2). While the second quarry site is of sandstone rocks lying 2-3 km southward of Wade Ayan. The exposed limestones rocks are bedded, massive and have marl interbeds with total thickness of about $500 \mathrm{~m}$ (Beydoun, et al., 1998 and Al-Mashaikie, 2010). Calcite $\left(\mathrm{CaCO}_{3}\right)$ is the main component of the studied limestone including very low dolomite content $(0.5 \%)$ and attain various types of texture mostly of grainstone and wackestone microfacies (Flugel, 1982; Scholl and Ulmer-Scholl, 2003). It considered of very good quality for cement production (Harrison, 1993 Walter and Werner, 2003). The sandstone rocks are composed of silica grains partially cemented by calcite and clays.

\section{B. Chemical analysis of limestone rocks}

The limestone samples are analyzed by XRF-device (THRMO type) using laboratory of Amran Cement plant. The chemical analyses are listed in Table 4.

Table 3. The chemical analysis of the limestone raw materials shows percentages of major oxides with sulfate, phosphate and chloride content

\begin{tabular}{|l|c|c|c|c|c|c|c|c|c|c|c|c|c|}
\hline \multirow{2}{*}{$\begin{array}{l}\text { Sample } \\
\text { No. }\end{array}$} & \multicolumn{10}{|c|}{ Major oxides \% } \\
\hline WA-1 & $\mathbf{S i O}_{2}$ & $\mathbf{A l}_{2} \mathbf{O}_{3}$ & $\mathbf{F e}_{2} \mathbf{O}_{3}$ & $\mathbf{C a O}$ & $\mathbf{M g O}$ & $\mathbf{K}_{2} \mathbf{O}$ & $\mathbf{N a}_{2} \mathbf{O}$ & $\mathbf{M n O}$ & $\mathbf{T i O}_{2}$ & $\mathbf{S O}_{3}$ & $\mathbf{P}_{2} \mathbf{O}_{5}$ & $\mathbf{C I}$ & $\mathbf{L O I}$ \\
\hline WA-2 & 0.0 & 0.0 & 0.3 & 50.8 & 0.51 & 0.05 & 0.07 & 0.02 & 0.1 & 0.37 & 0.01 & 0.01 & 40.88 \\
\hline WA-3 & 0.0 & 0.0 & 0.36 & 54.8 & 0.33 & 0.1 & 0.01 & 0.02 & 0.06 & 0.1 & 0.01 & 0.0 & 42.94 \\
\hline WA-4 & 0.0 & 0.7 & 0.3 & 52.7 & 0.34 & 0.1 & 0.01 & 0.02 & 0.06 & 0.15 & 0.01 & 0.0 & 43.22 \\
\hline WA-5 & 0.0 & 0.0 & 0.4 & 54.9 & 0.47 & 0.04 & 0.03 & 0.02 & 0.07 & 0.25 & 0.01 & 0.0 & 43.45 \\
\hline WA-6 & 0.0 & 0.0 & 0.4 & 55.4 & 0.42 & 0.09 & 0.03 & 0.02 & 0.06 & 0.15 & 0.0 & 0.0 & 43.0 \\
\hline WA-7 & 0.0 & 0.0 & 0.33 & 55.6 & 0.41 & 0.1 & 0.02 & 0.02 & 0.05 & 0.2 & 0.0 & 0.0 & 42.58 \\
\hline WA-8 & 0.0 & 0.0 & 0.34 & 55.4 & 0.31 & 0.1 & 0.03 & 0.02 & 0.06 & 0.11 & 0.01 & 0.01 & 43.47 \\
\hline WA-9 & 0.0 & 0.0 & 0.34 & 55.5 & 0.32 & 0.1 & 0.02 & 0.02 & 0.06 & 0.12 & 0.0 & 0.01 & 43.47 \\
\hline WA-10 & 0.0 & 0.0 & 0.35 & 53.8 & 0.39 & 0.07 & 0.01 & 0.02 & 0.06 & 0.21 & 0.01 & 0.0 & 42.48 \\
\hline WA-11 & 0.0 & 0.0 & 0.34 & 55.0 & 0.29 & 0.11 & 0.0 & 0.02 & 0.06 & 0.09 & 0.0 & 0.0 & 42.97 \\
\hline
\end{tabular}

The chemical analysis reveals high $\mathrm{CaO} \%$ content with low $\mathrm{MgO} \%$ content. The silica, aluminum, iron oxides and alkalis are very low percentages and not affect the quality of limestones. For this composition, the raw mixture needs additional correction using clayey soil or mudstones with silica sandstone and iron ore. The rocks are also containing very low phosphate $\mathrm{PO}_{3}$ salt $\mathrm{NaCl}$ and nitrates. During the explosion, the resulted high temperature make reaction between these components and gases will be liberated. Some of these gases are poisonous in certain amount, which are dissolved in the rainfall waters, forming polluted solutions for the waters. 


\section{Ambient Air Quality and Levels of Noises}

Yemen authorities have no real data for the quality of air pollution and noise levels. In Al-Ghareb site, an effort was carried to make informational data for air quality and noise level. It is worth mentioned that this area lies near villages, populations and cried markets. Distributed villages and farms are the specific characters of the study area where agriculture and cried of sheep are the main works of the peoples. The traffics is far from the studied site and it is not polluted. The area is of quiet life atmosphere and low-density population (Table 4). In Al-Ghareb quarry site, air quality and dust content is coinciding with the limits of EPA standards Guidelines (1986); USEPA (2002a); EPA (2013) (Table 5). Production of 3000 ton/day cement of Al-Nawaser factory needs large quantities of raw materials, which act to pollute the air directly from quarry operation processes.

Table 4. Measured weather data and dust concentrations in in Al-Ghareb area morning

\begin{tabular}{|c|c|c|c|c|c|c|c|c|c|}
\hline Time & Location & $\begin{array}{c}\text { PM1 } \\
\mu \mathrm{g} / \mathrm{m}^{3}\end{array}$ & $\begin{array}{l}\text { PM2.5 } \\
\mu g / \mathrm{m}^{3}\end{array}$ & $\begin{array}{c}\text { PM4 } \\
\mu g / \mathbf{m}^{3}\end{array}$ & $\begin{array}{l}\text { PM10 } \\
\mu g / \mathbf{m}^{3}\end{array}$ & $\begin{array}{l}\text { PM10 } \\
\mu g / m^{3}\end{array}$ & TSP & $\begin{array}{l}\text { Ambient } \\
\text { Temp. }{ }^{0} \mathrm{C}\end{array}$ & $\begin{array}{c}\text { Relative } \\
\text { Humidity } \%\end{array}$ \\
\hline 08:30 & $\begin{array}{l}\text { Al'loha area beside the } \\
\text { main road of Hajjah }\end{array}$ & 16 & 13.7 & 40.7 & 71.2 & 91.1 & 116 & 35 & 48 \\
\hline $08: 38$ & $\begin{array}{l}\text { Villages at the open area } \\
\text { front of Wade Ayan }\end{array}$ & 19 & 16.4 & 54.3 & 100.7 & 125.9 & 143.4 & 34 & 52 \\
\hline $08: 48$ & $\begin{array}{l}\text { Open limit of Wade } \\
\text { Ayan, northwards }\end{array}$ & 17 & 13.9 & 42 & 78.7 & 103.6 & 136.9 & 35 & 49 \\
\hline 08:50 & $\begin{array}{l}\text { The farms between } \\
\text { Al'loha and Wade Ayan }\end{array}$ & 16 & 13.1 & 38.4 & 73.1 & 103.7 & 135.3 & 34 & 52 \\
\hline $08: 55$ & $\begin{array}{l}\text { Al-Daher area at the } \\
\text { main road }\end{array}$ & 19 & 13.3 & 36.6 & 58.5 & 68.8 & 79.2 & 34 & 49 \\
\hline 09:27 & North Al-Hamedah area & 17 & 14.1 & 42.1 & 75.9 & 95.4 & 109.5 & 35 & 49 \\
\hline $9: 35$ & $\begin{array}{l}\text { Wade Ayan, South Al- } \\
\text { Hamedah area }\end{array}$ & 17 & 13.8 & 42.1 & 75.7 & 97.2 & 119 & 36 & 44 \\
\hline 10.05 & Al-Ghareb village & 20 & 17.4 & 54.1 & 100.9 & 131.8 & 159.2 & 36 & 49 \\
\hline
\end{tabular}

Table 5. Proposed standards in view of air quality

\begin{tabular}{|l|c|c|c|}
\hline \multirow{2}{*}{ Pollutant } & $\begin{array}{c}\text { Pollution } \\
\text { Ratio }\left(\boldsymbol{\mu g} / \mathbf{m}^{\mathbf{3}}\right)\end{array}$ & $\begin{array}{c}\text { Average Duration of } \\
\text { Measurement }\end{array}$ & Competent Authorities \\
\hline \multirow{3}{*}{ Fine Dust (PM-10) } & 50 & Annual & Yemen \\
& 100 & Daily & Annual \\
& 50 & Daily & American Authority for Environment \\
& 150 & Annual & Drotection \\
\hline \multirow{3}{*}{ Dust / Suspended Particulates } & $60-90$ & Annual & World Health Organization \\
\cline { 2 - 4 } & $150-230$ & Daily & European Union \\
\hline \multirow{2}{*}{ Sulfur Dioxide $\left(\mathrm{SO}_{2}\right)$} & 300 & Annual & Yemen \\
\hline \multirow{2}{*}{ Nitrogen Dioxide $\left(\mathrm{NO}_{2}\right)$} & 50 & Daily & Daily \\
\hline
\end{tabular}


The source of pollution is resulting from; (1) blasting of dynamite, (2) drilling machine and poclain operations, (3) Shovels, (4) Vehicles and trucks (5) Three types of primary crushers in the site to get smaller pieces (Lilic et al., 2018).

\section{Potential Environmental Impacts}

Potential environment impacts are resulted from operations in the quarry site. The expected polluted parameters represented natural resources including surface ground waters, soil, biological activates, landscape and air and populations. Health and safety factors are affected. Impacts is assessed by measurement devices and the data is presented by computer programs. Another impacts are defining by qualitative comparison with previous observations, USEPA (1974), USEPA (1997) and ELAW (2010) guidelines. Agricultural area is exposed near villages and residential units in which pollution impact is linked with exposed locations such as local areas, schools and offices (Fig. 3) and (Table 6).

Table 6. Types of emitted dust during cement processes (VD, 1985 and USEPA, 1995a)

\begin{tabular}{|l|c|}
\hline Type of dust & Methods of formation during manufacturing processes \\
\hline Dust resulting from Raw Materials & Drilling, bombing, crushing, cracking and transfer of raw materials \\
\hline Dust resulting due to feeding of materials & $\begin{array}{c}\text { Feeding, milling, storage, mixing and transfer of materials during the } \\
\text { manufacturing process }\end{array}$ \\
\hline Dust resulting from Kiln (Bypass) & $\begin{array}{c}\text { Feeding and treatment of materials relevant to counter-clockwise } \\
\text { rotation of hot gases in the Kiln }\end{array}$ \\
\hline Clinker Dust & Cooling of Clinker by means of air exposure, and storage \\
\hline Cement Dust & Feeding, milling, transport, packing and loading of cement \\
\hline
\end{tabular}

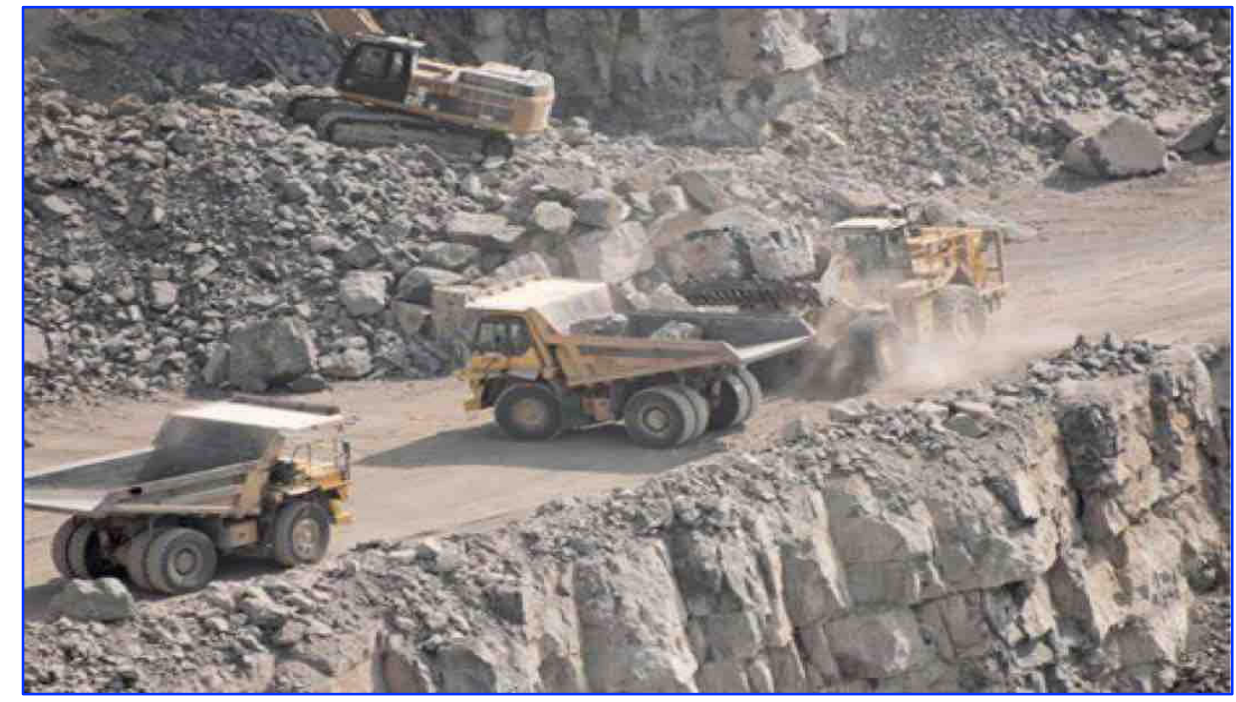

Fig. 3. The works in the quarry of raw materials shows the shovel, trucks and poclin 


\section{Types of Air Pollution}

Expected environmental impact assessment is focused on the air quality, which produced during the quarry processes. Extraction of the raw materials is emitted immense quantities of dust and gases generated from pitting, blasting of dynamites and the crushing of the rocks to finer size. The composition and size of dust particles are depending on the characteristics of the raw materials, where $\mathrm{CO}_{2}$ and other gases are emitted in real quantities during the quarry operations.

\section{Climate and Landscape}

Climatic data of weather forecast and topography give important data of impact parameters for dust and gases, which are emitting from the quarry site. Changes of weather conditions act to change pollution levels at the exposure sites. Collected data from Al-Hodiedah City have the same weather conditions in Al-Ghareb area and the monitoring air station is not existing.

Al-Ghareb region reveals complex topography, high mountains and steep valleys. The measured factory's surface level is $340 \mathrm{~m}$ a.s.l. and Al-Ghareb Mountain is $600 \mathrm{~m}$ a.s.l. The Google Earth utility is used and GIS program and Earth' DEM (NASA.USA). Classification of land uses is important to classify the lands uses near the site according to variable average dispersion between the villages and city environments followed the outlines of the USEPA $(1974 ; 1986)$. Density factor of population and land uses are hiring as standards to classify the air quality simulation programs, which is relevant in EPA. The plant site is occupied $5 \mathrm{~km}^{2}$ is suggested to considered the dispersion factors of the village environment (Table 7).

Table 7. Emissions from various sources of the open spaces of Al-Nawaser Cement plant site

\begin{tabular}{|l|c|c|c|c|c|}
\hline \multirow{2}{*}{ Source of emissions } & \multirow{2}{*}{ Area $\left(\mathbf{m}^{\mathbf{3}}\right)$} & \multicolumn{4}{|c|}{ Level of emissions $\left(\mathbf{m g} / \mathbf{s e c}^{\mathbf{m}} \mathbf{m}^{\mathbf{3}}\right)$} \\
\cline { 3 - 6 } & & Without control systems & \multicolumn{2}{|c|}{ Effectiveness of controlling methods } \\
\cline { 3 - 6 } & & & $\mathbf{2 5 \%}$ & $\mathbf{5 0} \%$ & $\mathbf{8 0} \%$ \\
\hline The quarry site & 40,000 & 0.33 & 0.25 & 0.17 & 0.07 \\
\hline Quarry after expansion & 106,929 & 0.33 & 0.22 & 0.17 & 0.07 \\
\hline AL-Nawaser Cement plant & 263,000 & 0.30 & 0.51 & 0.34 & 0.06 \\
\hline $\begin{array}{l}\text { AL-Nawaser Cemen after } \\
\text { expansion of production line }\end{array}$ & 263,000 & 0.68 & 0.14 \\
\hline
\end{tabular}

\section{Dispersion Modeling System}

Potential data of dust dispersion used in GIS modeling is applied for annual pollution plotted on the google map covering the plant site, villages and surrounding areas (Fig. 4). GIS pro version 4.13 model of BREEZE ISC program used to get real data, followed the model of (USEPA, 2002) 
to evaluate the impacts of emitted gases and dust. Interpretative data of dust levels is shown in Table 7 and absence of pollution control in the site led wide areas is subjected to emission levels exceed permitted standards of EPA (2013).

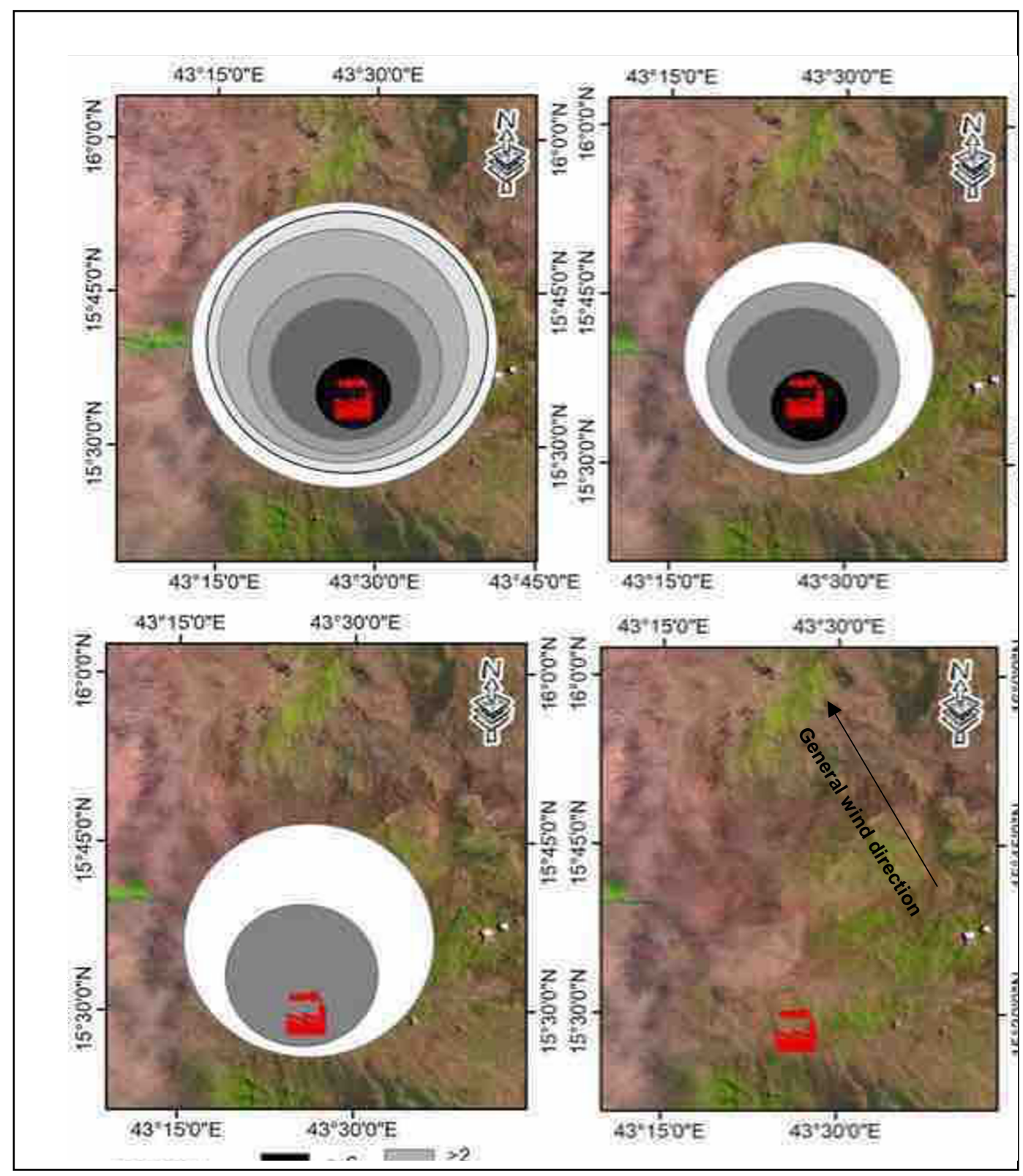

Fig. 4. Annually PM exposure levels for Al-Nawaser cement quarry site under proposed production capacity of 3,000,000 tons/year (BAT: Best Available Technology)

Note the wind direction in the lower right edge of the photo (above left) S1.1: With no emission control

(above right) S1.2: With a control efficiency of $50 \%$ for point and $25 \%$ of area source (lower left) S1.3: With control efficiency of $80 \%$ for point sources and $50 \%$ of area source (lower right) S1.4: With BAT for point sources and $80 \%$ control efficiency for area sources 


\section{Limitation}

Many limitations are used to define the impacts during the quarry operations. The absence of real and long-term specific data may not give a precise description of the real conditions for NCP operation processes and environmental parameters in Al-Ghareb area. It is necessary to use the monitoring program and re-assess the data and validity of the same exposure levels based on data of long-time/systematic monitor. Program models are only compatible to provide approximate general view of exact processing time and to make best comparison purposes. Models of air dispersion including ISC program show increases of uncertain short-term periods and average increase/decrease of average periods to get more correct annual exposure levels than daily levels.

\section{A. Vibration and noise levels}

The Noise is abnormal sound having many different effects on the human health and surrounding environment. Many parameters other than the exposures are largely influence the community to react with noise such as duration and noises frequency of open/closed windows, day time effect, outdoor noise level in absence of quarry noises, noise source relative to time of previous exposure, exposure towards noise source and presence of pure vibrations (USEPA, 1974; EPA, 2013; Hernique and Zannin, 2013; Hegan and Hatton, 2016; Lili et al., 2017 and Lilic et al., 2018).

Intense quarry activities of heavy machines are resulted intermittent/ permanent high noise levels, can be reduce by accurate sitting and isolate the processing site (EPA, 2014). The intermittent noise is mainly resulted from drilling pit machines, blasting, the daily starting machines and rocks loading into dumpers (WBCSD, 2002). While the permanent noise can be generated from three main factors (WBCSD, 2002 and Lilic et al., 2018): 1) blasting of raw materials, 2) machines noise, the type and age of machines, older machines are generating higher noise levels, 3) transport limestone rocks by trucks and conveyer belts, 4) Noise crusher when crushing and grinding stone.

Noise levels impact is measured by Noise Meter/Sound Meter type PCE-322ALE, and data are compared to guidelines of the energy-equivalent noise levels for cement industry (EPA, 2013). Generated noise levels are exceeded the day and night times noises of the Yemeni standards for population and surrounding areas. Moreover, the standard for industrial areas is recommended to $2 \mathrm{Km}$ radius according this equation:

$\mathrm{Leq}=42.3+10.2 \log (\mathrm{Vc}+6 \mathrm{Vi})-13.9 \log \mathrm{D}+0.13 \mathrm{~S}$ (Hajek 1977) in Alexander and Banaadornwi (2013). 
L- energy equivalent sound level during 1hour (in dBA), Vi-volume of automobiles (vehicles. h), $\mathrm{V} c$ - volume of trucks (vehicles. h), D- distance from edge of pavement to receiver (m), S- average speed of traffic flow during 1 hour $\left(\mathrm{km} / \mathrm{h}^{-2}\right)$.

The on-sit noise effect is the workers subjected to increase noise levels for $8 \mathrm{hr}$ as average period. Almost noise levels data measured in the site are more than 90 (dBA) 8-hour occupation to noise according to the standards of the Occupational Safety and Health Administration (Marmaya and Mahbub, 2018; OSHA manual, 2011 and OSHA, 2015). The vibration levels generated by detonation of the raw materials and heavy machine on or outside the area. The vibration levels generated by operation are less than to cause damage in the buildings. Moreover, the pressure waves moveable vibrations via air and ground ("overpressure") are shaking the houses and populations. For this case, detonation is important to avoid the local people and residential units surrounding NCP.

Table 8. Expected noise levels measurement in NCP compared with typical energyequivalent noise levels reported for the cement industry (ETPI 1999)

\begin{tabular}{|l|c|c|}
\hline \multirow{2}{*}{ Location } & \multicolumn{2}{|c|}{ Noise levels(dBA) } \\
\cline { 2 - 3 } & Measured noise levels & Typical noise levels \\
\hline Quarry & NR & $87-106$ \\
\hline Crusher & NR & $90-105$ \\
\hline Raw mill & $98-103$ & $97-115$ \\
\hline Kiln & $91-96$ & $97-115$ \\
\hline Cement Mill & $93-104$ & $91-107$ \\
\hline
\end{tabular}

NR: Not recorded

1: Measured at $7.5 \mathrm{~m}$ from source $\quad 2$ : Value measured during the loading and transport of raw materials

Table 9. Estimated noise levels of mining, transported and extraction vehicles and crushers.

\begin{tabular}{|l|c|}
\hline Equipment & Noise level (dB(A)) \\
\hline Trucks & 110 \\
\hline Shovels & 115 \\
\hline Bulldozers & 118 \\
\hline Drilling rigs & 103 \\
\hline Primary and secondary crushers & 117 \\
\hline Crushers (overburden) & 107 \\
\hline
\end{tabular}

\section{DISCUSSION}

\section{Mitigation Protection Plan}

Negative primary potential impacts produced by quarry processes can be decrease by mitigation plan, adopted suitable managing practices depending of effective monitoring plan. The proposed 
mitigation plan suggests many expected impact-control measures to decrease the probable distributed impacts and to decrease the permanent or temporary effects of potential EI.

\section{A. Mitigation to reduce the air quality-dust impact}

Many mitigation plans are available to decrease various impacts of air pollution, including specific efficiency treatments, economic and techniques demands. Mitigation of air quality is ranging between BAT and low-cost treatments. NCP suggests many mitigation plans, where PM emitted dust is the prior to reduce. Quarry operations emit real quantities of PM by extracting, transporting and grinding limestone rocks. The source of emitted PM comes from extraction, transportation and storage of raw limestone materials (Table 9). These factors are generating real quantities of dust effected directly the areas around the site. mitigation plans are discussed in the Table 10 below.

Table 10. Common control measures for particulate emissions from quarry operations for cement manufacture (I LO Codes, 1984; USEPA, 1997 and IEA, 2007)

\begin{tabular}{|l|l|l|l|}
\hline Category & Source & Measure and description 1 & $\begin{array}{l}\text { Emission } \\
\text { reduction } \\
\mathbf{( \% )} \mathbf{2}\end{array}$ \\
\hline \multirow{4}{*}{$\begin{array}{l}\text { Point } \\
\text { source }\end{array}$} & Crusher & Fabric filters: pulse jet, reverse air, or shaker bag house & $99.6-99.9$ \\
\cline { 2 - 4 } & Raw mill & Fabric filters: pulse jet, reverse air, or shaker bag house & $99.6-99.9$ \\
\hline \multirow{4}{*}{$\begin{array}{l}\text { Fugitive } \\
\text { sources }\end{array}$} & Quarry site & $\begin{array}{l}\text { Water sprays with and without surfactants, foams, chemical dust } \\
\text { suppressants, wind screens, equipment enclosures, and paving }\end{array}$ & Not available \\
\cline { 2 - 5 } & Storage areas & $\begin{array}{l}\text { Closed silos with air-filtering separators, closed sheds } \\
\text { (tents/umbrellas) with automatic handling system, wind breaks, } \\
\text { pile covers }\end{array}$ & Not available \\
\cline { 2 - 5 } & Traffic areas & Paving, cleaning, wetting, speed limit, housekeeping & Not available \\
\cline { 2 - 5 } & $\begin{array}{l}\text { Conveyor } \\
\text { system/Transfer } \\
\text { points }\end{array}$ & $\begin{array}{l}\text { Closed pneumatic conveyors, closed hoppers with fabric filters, } \\
\text { drop height reduction }\end{array}$ & Not available \\
\hline
\end{tabular}

1 EA 2001; Cembureau 1999; Inece 1998; Usepa 1995a; Awma 1992; VDI, 1985, 2 Awma, 1992

\section{B. Mitigation of traffic impacts}

Suggested mitigation plan for traffic impacts need primary schedule to order the transportation of the limestone pieces to the storage yards. Respectively, a suitable specific plan for vehicle accounts to prevent and decreases the potential noises to proper safety state. The traffic vehicle must be decreases to off-peak time for feasible effect. Moreover, enough distance needs at $500 \mathrm{~m}$ around the quarry to save people from the frequent effects of heavy machines traffic (Table 10). 
Table 10. Traffic control measures in the quarry site of NPC

\begin{tabular}{|c|c|}
\hline $\begin{array}{l}\text { Control measure } \\
\text { Typical examples }\end{array}$ & Control measure Typical examples \\
\hline On-site & $\begin{array}{l}\text { - Local entrance and exit to provide maximum turning space and sight lines } \\
\text { - Predominant traffic flow direction of vehicle movement } \\
\text { - Adequate off-loading and loading space to ensure vehicles can wait on-site } \\
\text { - Adequate off-street parking for employees } \\
\text { - One-way traffic within the site to prevent obstruction to vehicles enter and exit } \\
\text { - Speed restrictions on vehicles entering and leaving the site }\end{array}$ \\
\hline Off-site & $\begin{array}{l}\text { - Routing of traffic to and from NCP to avoid residential areas } \\
\text { - Scheduling of deliveries and departures to avoid over-night parking } \\
\text { - Ensure that vehicles and containers are suitable for transport and are adequately maintained } \\
\text { - Use of locally designated traffic routes }\end{array}$ \\
\hline
\end{tabular}

\section{Mitigation of noise impacts}

The expected noise impact in the quarry site is exceeding than the day and night times as reported in Barrientos, et al. (2004) and Al-Mashaikie, Al-Karraz (2013), Hernique and Zannin, (2013), Hegan and Hatton, (2016), Lili et al., (2017) and Lilic, et al. (2018). Mitigation plan should be dependent to decrease the impacts of noises to save receptors. Suggested noise barriers are used to insulate and reduce noise sources to $10 \mathrm{dBA}$, which usually built by suitable material to put along active work sites. The noise barriers are movable with proper distance and small cantilevered. Removable barriers must be sited within few meters of NCP site and about $5 \mathrm{~m}$ of movable machines to attenuate noise to $10 \mathrm{dBA}$ (EPA 2013). Additional mitigation measures include select quiet machines, adopting suitable operations schedule during 7:00 am to 6:00 pm time. Moreover, onsite suitable managed mitigation steps suggest reducing day emitted noises, including; Maintain machines on-site, using low noise machines, using rubber coating insulators in dumpers, using earplugs for safety, using greenbelt agriculture and installing barriers around the quarry. NCP should follow standards of WBCSD World Business Council for Sustainable Development (2002) for mitigation and minimize ground vibrations resulted from detonation in the quarry site:

1) limit blast to trained persons, 2) periodic vibrations records of detonation, 3) blasting limit to acceptable work hours for nearby receptors, 4) giving the blasting schedule to receptors, 5) using mille-second delay detonator, 6) using another technique to minimize of noise and vibrations, and 7) recommend uses of surface mining. 


\section{Mitigation for soil, surface and ground water impacts}

Expected impact sources of soil and water quality come from direct runoff of wastewaters and surface and groundwater. Therefore, open tanks covered by tarpaulin should be used during rainfall to prevent washing away. The quarry earthworks must be compacted to prevent erosion by wind or rainfalls. Moreover, make a suitable drainage regime with settling tank is proper to minimize the subjected period to effective discharge sources. Clearwater of settling tanks can be reused in NCP operations, irrigation and groundwater recharge. Spillages of fuel/waste should be clean and dried fuel are carried to landfill, and fuel should be collected in containers and re-used later.

Another impact of potential water pollution is the leak of oil/fuel, seeps to soil with disposal liquid effluents. Improper fuels handle at receiving area led to potential pollution source. Impermeable and resistant fuel tanks must collect and store oils to prevent drains or taps that act to blind collection point affected the pipes within the restricted areas and to prevent environmental damage. Moreover, suggested mitigate to avoid potential pollution of oil-fuel waste from machine services, wash and lubrication bays is to construct oil-water separators and sand precipitators pools and provides oil collection trays at the service sector (World Bank, 1998). The waste of motor oils in the service sector must be collected in sealed tanks and stored in closed drums to recycle. Oil must be removed from contaminated cooling water to treat in separators and re-used the conditioning tower and mill to cool the flue gases (World Bank, 1993; IEA, 2007; NPI, 2008 and EPA, 2018). The discharge of suspended solids is high relative to the receipted waters, while treatment required to minimize levels to maximum of $50 \mathrm{mg} / 1$ needs to discharge to surface waters (PM10 SIP, 1986; World Bank, 1998; IEA, 2007; NPI, 2008 and EPA, 2018).

\section{E. Mitigation plan for protect Biodiversity}

The existing vegetation and trees should be protected to avoid fires, prevent hunting and fuel and oil dispose wastes. Effort should also be made to prevent hazards in opened areas, an on-site program to mitigate the landscaping, suggest plans to restorative and reforestation around and inside the quarry site. These plans should be coordinate with Yemini Governorate to use original flora in re-vegetate on-site since to re-vegetate the area with local fauna. Several suggested steps must be considered close to the quarry to ensure the reintegration of the area with around (EPA, 1986) including: A) wastes removing, B) construct walls to prevent cracks and dangerous collapse, C) facilitate re-vegetation of the walls and decrease compacted floors to ensure beautiful landscape, D) Keep the natural drainage on-site, and E) Re-vegetation using original national vegetation. 


\section{CONCLUSIONS}

Environmental impact assessment is studied for the limestone quarry of Al-Nawaser cement plant in Al-Mahweet, NW Yemen. Processing at the quarry site was assessed to cover the detonation of dynamite, heavy machines working and traffics of shovels, trucks and crushers. Pollution impacts of dust, noise, gas emissions from machines, vehicles, fuel/oil wastes were evaluating. Mitigation plans are suggested and discussed to avoid the impacted pollution, which is affected by the surrounding environments. The selection of the quarry site is an important point to mitigate pollution impacts to save villages and human populations followed the national and international guidelines. Operational machines emitted dust and gases making impacts on environmental parameters.

\section{ACKNOWLEDGMENTS}

Thanks Dr. Younis Al-Sa'adie, the Head of the Information Department in the GEOSURV-Iraq, who help us in drawing the modeling program for Annually PM exposure levels. The authors are very grateful to the Editor in Chief Prof. Dr. Salih M. Awadh, the Secretary of Journal Mr. Samir R. Hijab and the Technical Editor Dr. Heba S. Al-Mimar for their great efforts and valuable comments.

\section{REFERENCES}

Alawi, A. J., Mezhelovsky, N.V., 1999. Republic of Yemen: Groundwater resources available for development. New York: Oxford University, Press, Inc. USA.

Al-Mashaikie, S. Z. K., Al-Karraz, K.A., 2013. Environmental impact assessment of Al-Maroua'ah cement plant factory in Al- Hodiedah Governate, Yemen, Report.

Alexander, O. N, and Banaadornwi, Y. 2013. A Review of modeling as a tool for environmental impact assessment. IREJEST. 10 (1).

AWMA. 1992. Air and waste management association, air pollution engineering manual. New York: Van Nostrand Reinhold.

Barrientos, M. C, Lendrum, D. C., Steenland, K. 2004. Occupational noise, assessing the burden of disease from workrelated hearing impairment at national and local levels, environmental Burden of disease series, No. 9. World Health Organization (WHO), Protection of the Human Environment.

Benjamin, A.O. 2008. Fundamental principles of occupational health and safety, International Labor Office. GENEVA Second edition, 221p.

Beydoun, Z. R., Sururi, M. A, El-Nakhal, H., Al-Ganad, I., Baraba, R., Nani, A. S., Al-Awah, M., 1998. International Lexicon of Stratigraphy, Asia, Republic of Yemen. 26: 517-529.

EPA. 1986. Guideline on air quality models (Revised). Environmental Protection Agency, Research Triangle Park, NC 27711, U. S.

EPA. 2013. Environmental guidelines for preparation of an environment management plan." Environment and Sustainable Development Directorate, ACT Government. Document. Australian Capital Territory, Canberra.

EPA., 2014. Guidelines for the preparation of noise management plans for development applications document. Environment Protection Authority (EPA). 
EPA., 2018. The drinking water standards and health advisories. Office of Water U.S. Environmental Protection Agency Washington, 18-001: 20.

FAO., 1996. Food and agriculture organization. Appraisal of the groundwater resource in the Amran region, Sana'a governorate, Technical Report UTF/YEM/020/YEM. Sana'a, Yemen.

Flugel, F. 1982. Microfacies Analysis of Limestones, book. Berlin, Heidelberg: Springer-Verlag.

Hajek, J. 1977. Traffic Noise Pollution Method. Environmental and Conservation Concerns in Transportation. Energy Noise and Air Quality, (Transportation Research Record No. 648). Transportation Research Record National Academy of sciences, 16-32.

Harrison, D. J., 1993. Industrial mineral laboratory manual limestone, Technical Report WG/92/29 Mineralogy and Petrology Series. British Geological Survey, 1993.

Hegan, T., and Hatton, L. 2016. Environmental Noise Assessment. Peak Acoustics Ltd Fernbank House, Macclesfield. Hernique, P., and Zannin, T., 2013. Noise and Ergonomics in the Workplace. Business, Competition and Entrepreneurship Published by Science Nova Publishers. Inc. New York.

GSMRB., 2013. Geological assessment of quarry limestone raw materials for cement industry in Jabal Falafel Mountain, Al-Hodiedah Governate. Report, Geological Survey and Mineral Resources Board (GSMRB), License and Report.

IEA., 2007. International Energy Agency. France.

I LO., 1984. Codes of Practice. Protection of Workers Against Noise and Vibration in the Working Environment. Switzerland: International Labor Office Geneva.

IPPC., 2001. Integrated Pollution Prevention and Control. Guidance for the Cement and Lime Sector, Sector Guidance Note IPPC S3.01. EA Environment Agency, Bristol, UK.

INECE., 1998. International Network for Environmental Compliance and Enforcement, Training course for multimedia inspectors. Industrial processes. Cement industries.

Iskander, A.W.A., 2010. Compiled in collaboration with international \& national technical consultant teams. Republic of Yemen, Ministry of Agriculture and Irrigation, Final Report-Project.

Lilic, N., Cvjetic, A., Knezevic, D., Milisavljevic, V., and Uros Pantelic, U., 2018. Dust and noise environmental impact assessment and control in Serbian Mining practice. Minerals, 8: 34; doi:10.3390/min8020034.

Lili, N. M., Cvjetic, A. S., Milisavljevic, V. M., Pantelic, U.R., Kolonja, L. R., 2017. Environmental Noise Management in the Area of Opencast Mines. Tehnika-Rudarstvo, 68.

MAI. 2007. Agricultural Statistics. Ministry of Agriculture and Irrigation, Book.

Marmaya, E. A., and Mahbub, R. 2018. A comparative study on the Environmental Impact Assessment of industrial projects in Malaysia. IOP Conference Series. Earth and Environmental Science, 117: 012020.

MoWE/EPA., 2004. National biodiversity strategy and action plan, Sana'a, Republic of Yemen, Ministry of Water and Environment/Environmental Protection Authority (MoWE/EPA), Report.

NPI., 2008. National Pollutant Inventory, "Emission estimation technique manual for cement manufacturing," Version 2.1, Department of the Environment, Water, Heritage and Art, Australian Governate, Document.

NWRA., 1999. Yemeni standards for the discharge of industrial and commercial wastewater," (National Water Resources Authority (NWRA), Sana'a, Yemen.

OSHA., 2011. Field Safety and Health Manual. US Department of Labor, Occupational Safety and Health Administration, OSHA Safety and Health Management System, 265p.

OSUA, 2015. Training Requirements in OSHA Standards, Occupational Safety and Health Administration U.S. Department of Labor, OSHA 2254-09R 2015, 270p.

PM10, S. I. P., 1986. Development Guideline, "EPA-450/2-86-001, U.S," Environmental Protection Agency USEPA, Research Triangle Park, NC 27711, U. S.

Scholl, P. A. and Ulmer-Scholl, D. S., 2003. A Color Guide to the Petrography of Carbonate Rocks: Grains, Textures, Porosity, Diagenesis, American Association of Petroleum Geologists (AAPG), Oklahoma, USA.

Tucker, M. E., 1988. Technique in Sedimentology. Oxford, London: Blackwell Scientific Publication.

USEPA., 1974. United States Environmental Protection Agency, Protective noise levels: Condensed version of EPA levels document, 550/9-79-100. Washington DC, USA: Office of Noise Abatement and Control. 
USEPA., 1997. United States Environmental Protection Agency, "Air quality index: A guide to air quality.

USEPA., 1997. United States Environmental Protection Agency, "Population risks from indirect exposure pathways, and population effects from exposure to airborne particles from cement kiln dust waste," Draft Report. Office of Solid Waste, United States.

USEPA., 2002. United States Environmental Protection Agency, Key topics, air.

Walter, L., Werner, G. 2003. Manual on the Geological Technical Assessment of Mineral Construction Materials, Geologisches Jahrbuch, Sonderhefte Reihe H, Heft SH 15BGR, Bundesanstalt fur Geowissenschaften und Rohstoffe, Geozentrum Hannover.

WBCSD., 2002. World Business Council for Sustainable Development, "Towards a sustainable cement industry."

WHO., 2018. A Manual for Protecting Health workers and Responders, Occupational Safety and Health in Public Health Emergencies, International Labor Office, World Health Organization, GENEVA, 150p.

World Bank, 1998. Pollution Prevention and Abatement Handbook - Part III: Cement Manufacturing. Washington, DC: World Bank, United States. 